Дитяча стоматологія

УДК 616.3-002-036.1-07-053.4

DOI 10.11603/2311-9624.2018.2.8814

\author{
( Л. Ф. Каськова, Т. Б. Мандзюк, С. Ч. Новікова, О. В. Хміль, Ю. І. Солошенко \\ вдНзУ «Українська медична стоматологічна академія», м. Полтава \\ ВДНЗУ «Буковинський державний медичний університет», м. Чернівці
}

\title{
Показники карієсу зубів у дітей в перший період змінного прикусу
}

Резюме. Карієс - найпоширеніша стоматологічна хвороба, що має свій початок у далекому минулому і на сьогодні є суттєвою проблемою дитячої стоматології. За даними ВОО3, близько 15 \% дітей другого року життя мають зуби, уражені карієсом. Показник підвищується з віком і у період змінного прикусу може сягати 90 \% залежно від місцевості, де проживають діти. Важливим є вивчення показників карієсу в дітей у період змінного прикусу, оскільки відбувається прорізування перших постійних молярів, які слабко мінералізовані, мають своєрідний рельєф жувальної поверхні. Діти в цей віковий період часто хворіють і недостатньо добре доглядають за порожниною рота.

Мета дослідження - вивчити показники карієсу в дітей у перший період змінного прикусу.

Матеріали і методи. Усього було оглянуто 134 дитини віком 7-9 років із першим періодом змінного прикусу в м. Полтаві. Поширеність карієсу визначали в відсотках. Групою порівняння слугували діти, обстежені в 1997-1998 рр. у м. Полтава. Отримані результати опрацьовані методом варіаційної статистики.

Результати досліджень та їх обговорення. Порівнювали показники карієсу з періодом 1997-1998 р. у вікових періодах 7; 8 і 9 років, що відповідає першому періоду змінного прикусу. В 82,22 \% дітей 8 років виявлено карієс тимчасових зубів. Ураження карієсом постійних зубів було у $14(31,11 \pm 6,98) \%$ оглянутих дітей. 13 із них, що становить $(92,86 \pm 7,14) \%$, мали і карієс тимчасових зубів. Досить важливим $є$ той факт, що лише у $2(14,3 \pm 9,71)$ \% дітей із 14 були запломбовані постійні зуби під час профілактичного огляду в дитячого стоматолога. Інші 12 дітей не знають, що в них є карієс у постійних зубах. Усі ці фактори необхідно враховувати під час проведення санітарно-просвітньої і профілактичної роботи дитячого лікаря-стоматолога.

Висновки. Аналіз показників карієсу тимчасових і постійних зубів у дітей у перший період змінного прикусу (7-9 років) м. Полтави в період спостереження в 1997-1998 рр. і 20 років потому (2017 р.) виявив певні відмінності. Значну увагу необхідно звернути на показники поширеності й інтенсивності карієсу тимчасових зубів у дітей 8 років. Вони значно вищі в 2017 порівняно з 1997-1998 рр. Особливу тривогу викликають дані про стан твердих тканин постійних зубів дітей сьогодення. Вони значно гірші, ніж 20 років тому. Це вимагає більш детального вивчення факторів, які можуть на це впливати, а також вивчення відношення дітей і їхніх батьків до збереження стоматологічного здоров’я, оскільки система роботи шкільних дитячих лікарів-стоматологів в м. Полтаві збережена, що є дуже важливим моментом із точки зору профілактики стоматологічних хвороб і своєчасної санації порожнини рота.

Ключові слова: карієс; розповсюдження; інтенсивність; змінний прикус.

\section{(СЛ. Ф. Каськова, Т. Б. Мандзюк, С. Ч. Новикова, Е. В. Хмиль, Ю. И. Солошенко}

ВГУзУ «Украинская медицинская стоматологическая академия», г. Полтава

ВГУзУ «Буковинский государственный медицинский университет», г. Черновцы

\section{Показатели кариеса зубов у детей в первый период сменного прикуса}

Резюме. Кариес - наиболее распространенная стоматологическая болезнь, которая имеет свое начало в далеком прошлом и сегодня является существенной проблемой детской стоматологии. По данным ВO3, около 15 \% детей второго года жизни имеют зубы, пораженные кариесом. Показатель повышается с возрастом и в период сменного прикуса может достигать 90 \% в зависимости от местности, где проживают дети. Важным является изучение показателей кариеса у детей в период сменного прикуса, поскольку происходит прорезывания первых постоянных моляров, которые слабо минерализованные, имеют своеобразный рельеф жевательной поверхности. Дети в этот возрастной период часто болеют и недостаточно хорошо ухаживают за полостью рта.

Цель исследования - изучить показатели кариеса у детей в первый период сменного прикуса.

Материалы и методы. Всего было осмотрено 134 ребенка в возрасте 7-9 лет с первым периодом сменного прикуса в г. Полтаве. Распространенность кариеса определялась в процентах. Группой сравне- 
ния служили дети, обследованы в 1997-1998 гг. в г. Полтаве. Полученные результаты обработаны методом вариационной статистики.

Результаты исследований и их обсуждение. Сравнительная характеристика показателей кариеса проводилась с периодом 1997-1998 гг. в возрастных периодах 7; 8 и 9 лет, что соответствует первому периоду сменного прикуса. В 82,22 \% детей 8 лет обнаружен кариес временных зубов. Поражение кариесом постоянных зубов наблюдалось у $14(31,11 \pm 6,98)$ \% осмотренных детей. 13 из них, что составляет $(92,86 \pm 7,14) \%$ имели и кариес временных зубов. Немаловажным является тот факт, что только у $2(14,3 \pm 9,71) \%$ детей из 14 были запломбированы постоянные зубы во время профилактического осмотра у детского стоматолога. Остальные 12 детей не знают, что у них есть кариес в постоянных зубах. Все эти факторы следует учитывать при проведении санитарно-просветительской и профилактической работы с детским врачом-стоматологом.

Выводы. Анализ кариеса временных и постоянных зубов у детей в первый период сменного прикуса (7-9 лет) г. Полтавы в период наблюдения в 1997-1998 г. и 20 лет спустя (2017) г. обнаружил определенные отличия. Значительное внимание следует обратить на показатели распространенности и интенсивности кариеса временных зубов у детей 8 лет. Они значительно выше в 2017 по сравнению с 1997-1998 гг. Особую тревогу вызывают данные о состоянии твердых тканей постоянных зубов детей современности. Они значительно хуже, чем 20 лет назад. Это требует более детального изучения факторов, которые могут на это влиять, а также изучение отношения детей и их родителей к сохранению стоматологического здоровья, поскольку система работы школьных стоматологов детских в г. Полтаве сохранена, что является очень важным моментом с точки зрения профилактики стоматологических заболеваний и своевременной санации полости рта.

Ключевые слова: кариес; распространенность; интенсивность; сменный прикус.

\section{F. Kaskova, T. B. Mandziuk, S. Ch. Novikova, O. V. Khmil, Yu. I. Soloshenko}

Ukrainian Medical Stomatological Academy, Poltava

Bukovyna State Medical University, Chernivtsi

\section{Indicators of dental caries in children in the first period of changeable occlusion}

Summary. Caries is the most common dental disease originating from the ancient past and nowadays it is a considerable issue of pediatric dentistry $(1,2)$. The WHO estimates approximately $15 \%$ of children in their second year of life are already teeth afflicted by caries. This indicator increases with age and in the period of changeable occlusion it can reach $90 \%$ depending on the territory where children reside. Investigation of caries indicators in children during the period of changeable occlusion is an important issue since eruption of the first permanent molars occurs, which are poorly mineralized, and have a specific relief of the masticatory surface (8). At this period of age children are often ill and do not thoroughly take care of their oral cavities $(9,10,12)$.

The aim of the study - to learn caries in children at the first period of changeable occlusion.

Materials and Methods. In general 134 children aged from 7 to 9 during the 1st period of changeable occlusion were examined. The comparative group included children examined in Poltava during the period of 1997-1998. The results obtained were processed by means of variation statistics method.

Results and Discussion. Comparative characteristics of caries indices was performed in the period of 1997$1998(3,4)$ at the age periods of 7,8 and 9 years which corresponds to the first period of changeable occlusion. $82.22 \%$ of 8-year-old children were diagnosed to suffer from caries of temporary teeth. 14 examined children $(31.11 \pm 6.98) \%$ had caries of the permanent teeth, including 13 of them with caries of temporary teeth $(92.86 \pm 7.14) \%$. An important fact was revealed that only in $2(14.3 \pm 9.71) \%$ children out of 14 permanent teeth were filled during preventive examination at the dentist. The rest 12 children were unaware of caries in their permanent teeth: carious cavities were small, toothache was absent; mastication surfaces were not accessible for careful examination by a child or parents; a dentist examination was more than half a year ago. All these factors should be considered while performing sanitary-educational and preventive work by a pediatric dentist.

Conclusions. The analysis of caries index of the temporary and permanent teeth in children during the first period of changeable occlusion (7-9 years of age) in Poltava during the period of investigation in 1997-1998 and 20 later (2017) determined certain differences. A considerable attention should be paid to the indices of occurrence and intensity of caries in 8-year-old children. They are rather higher in 2017 as compared to1997-1998. The data concerning the condition of the dental hard tissues of the permanent teeth in children nowadays are especially alarming. They appeared to be considerably higher than 20 years ago. It requires more detailed investigation of the affecting factors as well as the attitude of children and their parents to 


\section{Дитяча стоматологія}

dental health care, since the system of work of dentists in Poltava schools is maintained which is an important thing from the point of view of prevention of dental diseases and timely oral sanitation $(8,11)$.

Key words: caries; occurrence; intensity; changeable occlusion.

Вступ. В умовах розвитку сучасної стоматології можливість планування і проведення профілактичних заходів із метою підвищення резистентності твердих тканин зубів зумовлює необхідність вивчити показники карієсу в дітей різних вікових груп, порівняти їх з плином часу і визначити фактори, що сприяють виникненню карієсу.

Метою дослідження було вивчити показники карієсу в дітей у перший період змінного прикусу.

Матеріали і методи. Дослідження проводили на базі організованих дитячих колективів м. Полтави. Всього було оглянуто 134 дитина віком 7-9 років із першим періодом змінного прикусу. В усіх дітей визначали інтенсивність карієсу за показником КПВ+Кпв, де К - постійний зуб, уражений карієсом, П - постійний зуб, запломбований, В - постійний зуб, видалений 3 приводу ускладнень карієсу, к - тимчасовий зуб, уражений карієсом, п - тимчасовий зуб, запломбований з приводу карієсу. Тимчасові видалені різці й перші моляри не враховували в показник інтенсивності карієсу, оскільки вони знаходились в процесі зміни на постійні. Інші тимчасові зуби, видалені з приводу карієсу враховувались під час дослідження показника кпв. Поширеність карієсу визначали у відсотках. Групою порівняння слугували діти, яких обстежили в 1997-1998 pр. у м. Полтаві. Отримані результати опрацьовані методом варіаційної статистики. Вірогідними вважались показники при $\mathrm{p} \leq 0,05$.

Результати досліджень та їх обговорення. Ми обстежили 134 дитини з першим періодом змінного прикусу, тобто в порожнині рота прорізалися лише зуби із групи фронтальної ділянки (центральні й латеральні різці) та перші постійні моляри. Порівнювали показники карієсу з періодом 1997-1998 p. [3, 4] у вікових періодах 7; 8 і 9 років, що відповідає першому періоду змінного прикусу.

Аналіз результатів порівняння з 1997-1998 pp. показав, що дані щодо поширеності карієсу тимчасових зубів різняться у дітей 7 і 8 років (табл. 1). Так у 7-річних показники в 2017 р. вірогідно нижчий, ніж показник 1997-1998 pp. На нашу думку, це можна пояснити тим, що на сьогодні спостерігається більш рання заміна тимчасових різців, особливо верхньої щелепи, на постійні, а тимчасові різці, які відсутні в даний віковий період, а були уражені карієсом, не враховували в даний показник.

таблиия 1. Поширеність карієсу тимчасових зубів у дітей в перший період змінного прикусу

\begin{tabular}{|c|c|c|c|c|c|c|c|}
\hline \multirow{3}{*}{$\begin{array}{c}\text { Вік } \\
\text { (роки) }\end{array}$} & \multicolumn{2}{|c|}{ Кількість обстежених дітей } & \multicolumn{5}{|c|}{ Поширеність карієсу за показником кп, \% } \\
\hline & \multirow{2}{*}{$\begin{array}{c}\text { 1997-1998 } \\
\text { pp. }\end{array}$} & \multirow{2}{*}{2017 p. } & \multicolumn{2}{|c|}{ 1997-1998 pp. } & \multicolumn{2}{|c|}{2017 p. } & \multirow{2}{*}{$\mathrm{p}$} \\
\hline & & & абс. & $\%$ & абс. & $\%$ & \\
\hline 7 & 96 & 58 & 68 & $70,83 \pm 4,66$ & 30 & $51,72 \pm 6,62$ & $\leq 0,05$ \\
\hline 8 & 42 & 45 & 26 & $61,9 \pm 7,58$ & 37 & $82,22 \pm 5,76$ & $\leq 0,05$ \\
\hline $\mathrm{p}_{7-8}$ & & & & $\geq 0,05$ & & $\leq 0,05$ & \\
\hline 9 & 43 & 31 & 29 & $67,44 \pm 7,14$ & 21 & $67,74 \pm 8,93$ & $\geq 0,05$ \\
\hline $\mathrm{p}_{7-9}$ & & & & $\geq 0,05$ & & $\geq 0,05$ & \\
\hline $\mathrm{p}_{8-9}$ & & & & $\geq 0,05$ & & $\geq 0,05$ & \\
\hline Усього & 181 & 134 & 123 & $66,72 \pm 2,6$ & & $67,23 \pm 8,81$ & $\geq 0,05$ \\
\hline
\end{tabular}

Поширеність карієсу за показником кп у дітей 8 років також мав вірогідні відмінності в досліджуваних часових проміжках. У $(82,22 \pm 5,76) \%$ дітей, яких оглядали в 2017 р., виявлено карієс, тоді як в 1997-1998 рр. - у $(61,9 \pm 7,58) \%$ дітей.
Спостерігається вірогідне підвищення показника, можливо, за рахунок більш значного ураження тимчасових молярів, особливо других тимчасових молярів. У дітей 9 років поширеність карієсу тимчасових зубів має ідентичні показники, не залежно від часу до- 
слідження. Вікові періоди дослідження виявили вірогідні відмінності лише в дітей у період від 7 до 8 років у 2017 р.

Інтенсивність карієсу тимчасових зубів у дітей 7 років у 2017 р. була вірогідно нижчою, ніж у дітей в 1997-1998 р. спостереження (табл. 2). Це ми пояснюємо знову ж таки ранньою зміною тимчасових різців. У 8 і 9 років показник вищий у 2017 p. (p $\leq 0,05)$, що потребує більш детального вивчення причин такого явища. Найбільший приріст інтенсивності карієсу тимчасових зубів у період змінного прикусу на сьогодні спостерігаємо від 7 до 8 років. У період від 8 до 9 років показник зменшується за рахунок видалення перших тимчасових молярів.

Таблищя 2. Інтенсивність карієсу тимчасових зубів за показником кп

\begin{tabular}{|c|c|c|c|c|c|}
\hline \multirow{2}{*}{ Вік (роки) } & \multicolumn{2}{|c|}{ Кількість обстежених дітей } & \multicolumn{2}{|c|}{ Інтенсивність карієсу за показником кп } \\
\cline { 2 - 6 } & $1997-1998 \mathrm{pp}$. & $2017 \mathrm{p}$. & $1997-1998 \mathrm{pp}$. & $2017 \mathrm{p}$. & $\mathrm{p}$ \\
\hline 7 & 96 & 58 & $2,75+0,30$ & $1,62 \pm 0,25$ & $\leq 0,05$ \\
\hline 8 & 42 & 45 & $2,02 \pm 0,31$ & $3,22 \pm 0,50$ & $\leq 0,05$ \\
\hline $\mathrm{p}_{7-8}$ & & & $\geq 0,05$ & $\leq 0,05$ & $\leq 0,05$ \\
\hline 9 & 43 & 31 & $1,51 \pm 0,25$ & $2,42 \pm 0,44$ & $\geq 0,05$ \\
\hline $\mathrm{p}_{7-9}$ & & & $\leq 0,05$ & $\geq 0,05$ & \\
\hline $\mathrm{p}_{8-9}$ & & & $\geq 0,05$ & $2,42 \pm 0,46$ & $\geq 0,05$ \\
\hline Усього & 181 & 134 & $2,09 \pm 0,36$ & \\
\hline
\end{tabular}

Вивчення стану постійних зубів у дітей в різні періоди дослідження показали вагому різницю (табл. 3). Так, поширеність карієсу постійних зубів у дітей 7 років у 1997-1998 рр. складала $(3,13 \pm 1,8) \%$, а в 2017 - $(13,79 \pm 4,57) \%$ ( $\mathrm{p} \leq 0,05)$. Вірогідна була в кожному досліджуваному віковому періоді (у 8 років - $(7,14 \pm 4,02) \%$ у 1997-1998 pp. i $(31,10 \pm 6,98) \%$ у 2017 p., 9 років - $(18,6 \pm 5,93) \%$ і $(45,16 \pm 9,44)$ \% відповідно). Відмічаємо вірогідне збільшення поширеності карієсу постійних зубів у дітей в кожному віковому періоді порівняно 3 1997-1998 рр. Найвагоміше збільшення показника виявили в період від 7 до 8 років - на 17,31 \% у 2017 р. проти 4,01 \% в 2002 р., у період від 8 до 9 років - на 14,06 \% і 11,46 \% відповідно. 37 до 9 років поширеність карієсу постійних зубів збільшилась в 3,3 раза (дослідження 2017 р.) і в 5,94 ра- за (дослідження 1997-1998 рр.). Спостерігається значний приріст показника поширеності карієсу в кожний період дослідження, але ж нижчі показники були в 1997-1998 рр. У дітей 7-9 років поширеність карієсу постійних зубів становила $(9,62 \pm 4,63) \%$ у $1997-1998$ рр. та $(30,02 \pm 9,07) \%-$ у 2017 p.

Для розуміння ситуації із наявністю каріозного процесу в дітей у різні вікові періоди важливим є дослідження інтенсивності карієсу за показником КПВ. Наші дослідження і порівняння результатів сьогодення і 15-річної давності показали невтішну ситуацію щодо карієсу постійних зубів у дітей в перші роки після їх прорізування (табл. 4). Якщо інтенсивність карієсу постійних зубів у дітей 7 років у 1997-1998 рр. спостереження становила $(0,06 \pm 0,03)$ зуба, то в 2017 р. у дітей цього ж ві-

Таблищя 3. Поширеність карієсу постійних зубів у дітей в перший період змінного прикусу

\begin{tabular}{|c|c|c|c|c|c|c|c|}
\hline \multirow{3}{*}{ Вік (роки) } & \multicolumn{2}{|c|}{ Кількість обстежених дітей } & \multicolumn{5}{|c|}{ Поширеність карієсу за показником КПВ (\%) } \\
\hline & \multirow{2}{*}{ 1997-1998 pp. } & \multirow{2}{*}{2017 p. } & \multicolumn{2}{|c|}{ 1997-1998 pp. } & \multicolumn{2}{|c|}{2017 p. } & \multirow{2}{*}{$\mathrm{p}$} \\
\hline & & & абс. & $\%$ & абс. & $\%$ & \\
\hline 7 & 96 & 58 & 3 & $3,13 \pm 1,8$ & 8 & $13,79 \pm 4,57$ & $\leq 0,05$ \\
\hline 8 & 42 & 45 & 3 & $7,14 \pm 4,02$ & 14 & $31,10 \pm 6,98$ & $\leq 0,05$ \\
\hline $\mathrm{p}_{7-8}$ & & & & $\geq 0,05$ & & $\leq 0,05$ & \\
\hline 9 & 43 & 31 & 8 & $18,6 \pm 5,93$ & 14 & $45,16 \pm 9,44$ & $\leq 0,05$ \\
\hline $\mathrm{p}_{7-9}$ & & & & $\leq 0,05$ & & $\leq 0,05$ & \\
\hline $\mathrm{p}_{8-9}$ & & & & $\geq 0,05$ & & $\geq 0,05$ & \\
\hline Усього & 181 & 134 & 14 & $9,62 \pm 4,63$ & 36 & $30,02 \pm 9,07$ & $\leq 0,05$ \\
\hline
\end{tabular}


кового періоду цей показник підвищився в 3,5 раза і становив $(0,21 \pm 0,05)$ зуба на одного обстеженого. Така ж тенденція була і в 8 і у 9 років. Найбільший приріст інтенсивності карієсу постійних зубів і в 1997-1998 pp., і в 2017 р. ми спостерігали в період від 7 до 8 років, тобто це той час, коли необхідно приділити значну увагу вивченню факторів, що впливають на стан твердих тканин зубів та проведенню профілактичних заходів, спрямованих на підвищення резистентності твердих тканин постійних зубів.

Iз 58 обстежених дітей 7 років, обстежених у 2017 р., мали карієс тимчасових зубів 30 осіб, що становить $(51,72 \pm 6,62) \%$. Компоненту «К» мали 21 дитина із 30, що становить $(70 \pm 8,51) \%$.

таблиця 4. Інтенсивність карієсу постійних зубів за показником КПВ

\begin{tabular}{|c|c|c|c|c|c|}
\hline \multirow{2}{*}{ Вік (роки) } & \multicolumn{2}{|c|}{ Кількість обстежених дітей } & \multicolumn{3}{c|}{ Інтенсивність карієсу за показником КПВ } \\
\cline { 2 - 6 } & $1997-1998 \mathrm{pp}$. & $2017 \mathrm{p}$. & $1997-1998 \mathrm{pp}$. & $2017 \mathrm{pp}$. & $\mathrm{p}$ \\
\hline 7 & 96 & 58 & $0,06 \pm 0,03$ & $0,21 \pm 0,05$ & $\leq 0,05$ \\
\hline 8 & 42 & 45 & $0,17 \pm 0,10$ & $0,51 \pm 0,13$ & $\leq 0,05$ \\
\hline $\mathrm{p}_{7-8}$ & & & $\geq 0,05$ & $\leq 0,05$ & \\
\hline 9 & 43 & 31 & $0,28 \pm 0,11$ & $0,68 \pm 0,16$ & $\leq 0,05$ \\
\hline $\mathrm{p}_{7-9}$ & & & $\geq 0,05$ & $\leq 0,05$ & \\
\hline р8-9 & & & $\geq 0,05$ & $\geq 0,05$ & \\
\hline Усього & 181 & 134 & $0,17 \pm 0,06$ & $0,47 \pm 0,13$ & $\leq 0,05$ \\
\hline
\end{tabular}

Тобто санації підлягали 70,0 \% дітей, які мали карієс тимчасових зубів. Із них постійні зуби, уражені карієсом, були у 8 дітей, що становить $(13,79 \pm 4,57) \%$. У них були уражені й тимчасові зуби. При чому інтенсивність ураження тимчасових зубів була незначною (1-4 уражені зуби). Хоча це незначний відсоток, але необхідно акцентувати увагу на цей факт в перші роки після прорізування постійних зубів та вивчати фактори, що призводять до каріозного ураження.

У 82,22 \% дітей 8 років виявлений карієс тимчасових зубів. Ураження на карієс постійних зубів спостерігалося у $14(31,11 \pm 6,98) \%$ оглянутих дітей. 13 із них, що становить $(92,86 \pm 7,14) \%$, мали і карієс тимчасових зубів. Досить важливим $є$ той факт, що лише у $2(14,3 \pm 9,71) \%$ дітей із 14 були запломбовані постійні зуби під час профілактичного огляду в дитячого стоматолога. Інші 12 дітей не знають, що у них є карієс у постійних зубах: каріозні порожнини незначні, больових відчуттів немає, жувальні поверхні не доступні для ретельного огляду дитиною чи її батьками, останній раз оглядав стоматолог більше півроку тому. Всі ці факто-

\section{Список літератури}

1. Особенности стоматологического статуса населения территории Украины в разные исторические епохи / Л. Ф. Каськова, Л. І. Амосова, А. В. Артемьев [та ін.] // Медицинские новости Грузии. - 2014. № 12 (237). - С. 35-39.

2. Гринишин О. Б. Вікові особливості ураженості карієсом тимчасових зубів у дітей / О. Б. Гринишин // ри необхідно ураховувати під час проведення санітарно-просвітньої і профілактичної роботи з дитячим лікарем-стоматологом.

Висновки. Аналіз показників карієсу тимчасових і постійних зубів у дітей в перший період змінного прикусу (7-9 років) м. Полтави в період спостереження в 1997-1998 pp. і 20 років потому (2017 р.) виявили певні відмінності. Значну увагу необхідно звернути на показники поширеності й інтенсивності карієсу тимчасових зубів у дітей 8 років. Вони значно вищі в 2017 р. порівняно з 1997-1998 pр. Особливу тривогу викликають дані про стан твердих тканин постійних зубів дітей сьогодення. Вони значно гірші, ніж 20 років тому. Це вимагає більш детального вивчення факторів, які можуть на це впливати, а також вивчення відношення дітей і їхніх батьків до збереження стоматологічного здоров'я, оскільки система роботи шкільних дитячих лікарів-стоматологів в м. Полтаві збережена, що є дуже важливим моментом з точки зору профілактики стоматологічних хвороб і своєчасної санації порожнини рота $[8,11]$.

Експериментальна та клінічна фізіологія і біохімія. - 2015. - № 4. - C. 94-102.

3. Каськова Л. Ф. Поширеність та інтенсивність карієсу тимчасових зубів у дітей з родин ліквідаторів аварії на ЧАЕС / Л. Ф. Каськова // Вісник стоматології. -2000 . - № 2. - C. 51-52.

4. Каськова Л. Ф. Характеристика ураженості каріє- 
сом постійних зубів у дітей, які народились в сім'ях ліквідаторів аварії на ЧАЕС / Л. Ф. Каськова // Одеський медичний журнал. - 2000. - № 6 (62). - С. 100-101. 5. Захворюваність на карієс постійних зубів у дітей залежно від умісту фтору у питній воді та наявності флюорозу / Л. Ф. Каськова, Л. І. Амосова, О. Е. Бережна [та ін.] // Вісник проблем біології і медицини. 2015. - Вип. 2, Т. 2 (119). - С. 101-103.

6. Дєньга О. В. Поширеність і інтенсивність карієсу у дітей, які проживають в умовах дефіциту фтору в питній воді / О. В. Дєньга, М. Я. Пинда, В. В. Ковальчук // Вісник проблем біології і медицини. - 2014. T. 3, № 2. - C 328-330.

7. Характеристика ураженості карієсом перших постійних молярів залежно від їх одонтогліфіки у дітей м. Полтави / Л. Ф. Каськова, Ю. І. Солошенко, Л. І. Амосова [та ін.] / Світ медицини та біології. № 3(45). - 2014. - С. 62-64.

8. Мочалов Ю. О. Відродження шкільної стоматології - нагальна потреба системи охорони здоров'я

\section{References}

1. Kaskova, L.F., Amosova, L.I., \& Artemyev, A.V. (2014). Osobennosti stomatologicheskogo statusa naseleniya territorii Ukrainy $\mathrm{v}$ raznyye istoricheskiye epokhi [Features of the dental status of the population of the territory of Ukraine in different historical epochs]. Meditsinskiye novosti Gruzii - Medical News of Georgia, 12 (237), 35-39 [in Russian].

2. Hrynyshyn, O.B. (2015). Vikovi osoblyvosti urazhenosti kariiesom tymchasovykh zubiv u ditei [Age characteristics of lesions of caries of temporary teeth in children]. Eksperymentalna ta klinichna fiziolohiia $i$ biokhimiia - Experimental and Clinical Physiology and Biochemistry, 4, 94-102 [in Ukrainian].

3. Kaskova, L.F. (2000). Poshyrenist ta intensyvnist kariiesu tymchasovykh zubiv u ditei z rodyn likvidatoriv avarii na CHAES [Prevalence and intensity of caries of temporary teeth in children from families of liquidators of the Chernobyl accident]. Visnyk stomatolohii-Herald of Dentistry, 2, 51-52 [in Ukrainian].

4. Kaskova, L.F. (2000). Kharakterystyka urazhenosti kariiesom postiinykh zubiv u ditei, yaki narodylys $\mathrm{v}$ simiakh likvidatoriv avarii na CHAES [Characteristics of the caries of permanent teeth in children born in the families of liquidators of the Chernobyl accident]. Odeskyi medychnyi zhurnal - Odesa Medical Journal, 6 (62), 100-101 [in Ukrainian].

5. Kaskova, L.F., Amosova, L.I., \& Berezhna, O.E. (2015). Zakhvoriuvanist na kariies postiinykh zubiv $u$ ditei zalezhno vid umistu ftoru u pytnii vodi ta naiavnosti fliuorozu [The incidence of caries of permanent teeth in children depending on the fluoride content in drinking water and the presence of fluorosis]. Visnyk problem biolohii i medytsyny - Bulletin of Biology and Medicine, 2, (119), 101-103 [in Ukrainian].

6. Dienha, O.V., Pynda, M.Ya., \& Kovalchuk, V.V. (2014). Poshyrenist i intensyvnist kariiesu u ditei, yaki prozhyvaiut $\mathrm{v}$ umovakh defitsytu ftoru $\mathrm{v}$ pytnii vodi [Prevalence and intensity of caries in children living in conditions of fluorine deficiency in drinking water]. Visnyk problem biolohii i medytsyny - Bulletin of Biology and Medicine, 3 (2), 328-330 [in Ukrainian].

7. Kaskova, L.F., Soloshenko, Yu.I., \& Amosova, L.I. (2014).
України / Ю. О. Мочалов // Практика управління медичним закладом. - 2015. - № 2(49). - С. 64-72.

9. Смоляр Н. І. Оцінка визначення ступеню активності карієсу зубів у дітей шкільного віку, як одного із показників санації / Н. І. Смоляр // Вісник стоматології. - 2012. - № 2. - С. 97-100.

10. Солов'як О. О. Оцінка соматичного стану дітей із множинним карієсом / О. О. Солов'як, Н. I. Смоляр, Г. М. Солонько // Вісник проблем біології і медицини. - 2015. - Вип. 3, Т. 1. - С. 377-379.

11. Профілактична стратегія збереження стоматологічного здоров'я у дітей молодшого шкільного віку / Л. О. Хоменко, О. І. Остапко, І. М. Голубєва [та ін.] // Східноєвропейський журнал громадського здоров’я. - 2013. - № 1. - С. 269-270.

12. Смоляр Н. І. Мікрофлора зубного нальоту у дітей залежно від інтенсивності карієсу зубів / Н. І. Смоляр, Д. Ю. Бариляк / Профілактична та дитяча стоматологія. - Львів, 2013. - № 2. - С. 26-29.

Kharakterystyka urazhenosti kariiesom pershykh postiinykh moliariv zalezhno vid yikh odontohlifiky $u$ ditei m. Poltavy [Characteristics of the defeat of caries of the first permanent molars depending on their odontoglyphics in Poltava children]. Svit medytsyny ta biolohii - World of Medicine and Biology, 3 (45), 62-64 [in Ukrainian].

8. Mochalov, Yu.O. (2015). Vidrodzhennia shkilnoi stomatolohii - nahalna potreba systemy okhorony zdorovia Ukrainy [The revival of school dentistry is an urgent need for a health care system in Ukraine]. Praktyka upravlinnia medychnym zakladom - Practice of Management of a Medical Institution, 2 (49), 64-72 [in Ukrainian].

9. Smoliar, N.I. (2012). Otsinka vyznachennia stupeniu aktyvnosti kariiesu zubiv u ditei shkilnoho viku, yak odnoho iz pokaznykiv sanatsii [Estimation of the degree of activity of dental caries among school-age children as one of the indicators of rehabilitation]. Visnyk stomatolohii Herald of Dentistry, 2, 97-100 [in Ukrainian].

10. Soloviak, O.O., Smoliar, N.I., \& Solonko, H.M. (2015). Otsinka somatychnoho stanu ditei iz mnozhynnym kariiesom [Assessment of the somatic status of children with multiple caries]. Visnyk problem biolohii $i$ medytsyny - Bulletin of Biology and Medicine, 3 (1), 377379 [in Ukrainian].

11. Khomenko, L.O., Ostapko, O.I., \& Holubieva, I.M. (2013). Profilaktychna stratehiia zberezhennia stomatolohichnoho zdorovia $u$ ditei molodshoho shkilnoho viku [Prophylactic strategy for the preservation of dental health in children of junior high school age]. Skhidnoievropeiskyi zhurnal hromadskoho zdorovia - Eastern European Journal of Public Health, 1, 269-270 [in Ukrainian].

12. Smoliar, N.I., \& Baryliak, D.Yu. (2013). Mikroflora zubnoho naliotu $\mathrm{u}$ ditei zalezhno vid intensyvnost kariiesu zubiv [Microflora of plaque in children depending on the intensity of caries of teeth]. Profilaktychna ta dytiacha stomatolohiia - Preventive and Pediatric Dentistry, 2, 26-29 [in Ukrainian].

Отримано 05.04.18 